\title{
How the L.A. Riots Was Remembered in Korean Cinema: Western Avenue and Shattered American Dreams
}

\author{
Seung Hyun Park ${ }^{*}$, Yeonshik Kim(Corresponding author) ${ }^{* *}$ \\ *School of Communications, Hallym University, Chunchon, Gangwon-do, Korea \\ ${ }^{* *}$ Dep. of Journalism and Mass Communication, Kyungpook University, Daegu City, Korea
}

\begin{abstract}
The L.A. riots, which happened during three days from April 29 to May 1, 1992, are viewed as the most deadly and destructive riots in American history. Depicted in blaring front-page headlines and violent pictures on television, this urban upheaval received epic exposure in many countries. In Korea, it was especially shocking due to the viewpoint that highlighted the conflict between Korean and African Americans. This paper aims to review the black-Korean conflict during the 1992 L.A. riots in a Korean movie, Western Avenue. It is a film that narrates the despair of Korean Americans in the context of the L.A. riots, while placing American ideologies on trial. It is the only feature-length film to portray the story of Korean Americans in the L.A. riots. This paper examines some of the factors that resulted from the 1992 L.A. riots before the discussion of Western Avenue. Then, the paper analyzes the story of the Korean American in the film, focusing on how this film deals with the black-Korean conflict during the 1992 L.A. riots.
\end{abstract}

Keywords: Korean movie, film, Western Avenue, L.A. riots, Korean Americans, the black-Korean conflict

\section{INTRODUCTION}

The L.A. riots, which happened during three days from April 29 to May 1, 1992, are viewed as "the most deadly and destructive riots in American history."[1] Depicted in blaring front-page headlines and violent pictures on television, this urban upheaval received epic exposure in many countries partly because of what it said about the world's most powerful nation whose democratic values have been regarded with respect since the end of the Second World War. And in Korea, it was especially shocking due to the fact that approximately 200,000 Korean Americans were living in the area of Los Angeles at that time.[2] For Koreans, therefore, the L.A. riots were not so much a sensational international event captivating local attention as a life-and-death incident, especially for those Koreans who had relatives and friends in Los Angeles. The event was judged to be so important that 30 Koreans journalists were flown to Los Angeles to join in the coverage.[3] Via television screen, Koreans witnessed these riots in Los Angeles where many Korean American stores were burnt. Not only Koreans but also the world witnessed these riots via television screen. L.A. riots became the event of television where people recognized what happened in Los Angeles for three days. But movies seldom dealt with these riots. In a sense, film was not a medium portraying the story of Korean Americans during the

* Corresponding author,Email : yeondream@knu.ac.kr Manuscript received Oct. 04, 2012; revised Mar 09, 2013; accepted Mar 09, 2013

\section{L.A. Civil Unrest.}

This paper aims to review the black-Korean conflict during the 1992 L.A. riots in a Korean movie, Western Avenue (1993). Western Avenue, directed by Gil-Su Jang, is a film that narrates the despair of Korean Americans in the context of the L.A. riots, while placing American ideologies on trial. It is the only feature-length film to portray the story of Korean Americans in the L.A. riots. No other such movie has been made in Korea. [4] This movie could be an instance to look into how conventional elements of racial relations in the U.S. were intertwined in the life of Korean Americans. This paper will first examine some of the factors that resulted from the 1992 L.A. riots before the discussion of Western Avenue. Then, the paper analyzes the story of the Korean American in the film, focusing on how this film deals with the black-Korean conflict during the 1992 L.A. riots.
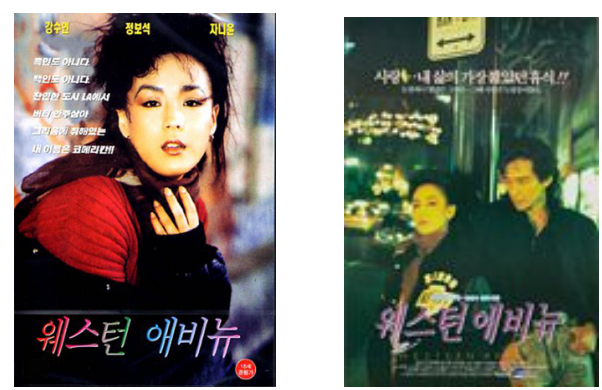

Fig. 1. $<$ Posters of Western Avenue $>$ 


\section{THE L.A. RIOTS AND KOREAN AMERICANS}

The upheaval in Los Angeles, the most favored city of Korean immigration in the land of new opportunity, was a watershed event for rethinking the life of Korean Americans in the United States, particularly in Southern California. Korean Americans showed a strong tendency toward small businesses. According to the 1990 U.S. census data, 24.3 percent of employed Korean Americans were self-employed and Koreans were ranked in the highest in self-employment among all U.S. ancestry groups.[5] Throughout the 1980s, American media had praised Korean American merchants as the model minority, realizing the American dream through the operation of small businesses. The Los Angeles Korean Chamber of Commerce estimated in 1990 that the total number of Korean Americanowned businesses in Los Angeles and Orange Counties amounted to over 11,000, including 3,300 markets and liquor stores.[6] Many Korean Americans who managed small businesses in that area worked hard for several years to open their stores, but these stores were destroyed overnight in the riots. While watching such media portraits as angry black protesters, the city on fire, the burning and looting of Korean American stores, and desperate Korean Americans for the protection of their stores, Koreans, whether living in Korea or foreign countries, witnessed their compatriots' American dreams being broken through violence. Koreans expressed shock at what they perceived as the deep racial divisions racking America and taking Korean Americans as scapegoats of African Americans' frustration. Especially Korean Americans expressed their anger and frustration with television and newspaper coverage of the riots and of Korean Americans.[7] This event eventually led Koreans to recognize that there was something deeply wrong with the American system: the threeday riots seemed to leave an impression that there was an absence of social legislation and protection in the American system.

The L.A. riots resulted in an estimated "58 dead, 2,400 injured, 11,700 arrested, [and] \$717 million in damages."[8] Many stores were burned and looted. Among them, Korean American businesses became the most spectacular target of burning and looting, in part, because most of them were in the center areas of the riots, located in South Central Los Angeles and in Koreatown adjacent to South Central. Approximately 2,300 stores owned by Korean Americans were damaged and destroyed. Forty-six Korean Americans were injured while trying to protect their stores and one was killed in riot crossfire. The financial loss of Korean American businesses was considered to be more than $\$ 300$ million. Even after the riots were over, Korean Americans had difficulty in overcoming the damage caused by the riots. They lost most of their shellstocked merchandise and their business records in fires, but were faced with needing to pay vendors or retailers. The Korean American Inter-Agency Council, in a survey of over 1,500 respondents ten months after the riots, found that "approximately 75 percent of the Korean American victims of the riots [had] not recovered from its after effects."[9] According to this survey, less than 28 percent of the respondents were able to reopen their businesses.

It is not easy to explain why African Americans mainly assaulted Koreans in L.A. Riots of 1992. Since Korean-black conflict is a complex issue, there can be single explanation of this conflict. Koreans' Prejudice on African Americans, language barriers, cultural differences, and alleged shoplifting and mistreatment of black customers are often the precipitating causes of numerous over-the-counter disputes between Korean store owners and black customers. Economic competition between Koreans and blacks can be a factor to cause the bad feeling of individual blacks toward individual Korean store owners in order to escalate into a collective opinion against Korean businesses as a group. Also, black nationalism can be a factor to cause black boycotts of Korean businesses to be used for political leverage for blacks to gain the economic autonomy in their communities.[10]

Some of Korean Americans who suffered damage or lost their businesses in L.A. Riots decided that they would not reopen their shops in that area at all. Others felt fear, but began to rebuild their stores because these stores were the very fruit of their hard work as well as the only way to feed their families. One Korean American shopkeeper whose store had suffered serious damage explained why he planned to rebuild his store, even though he knew the area was so dangerous. For him, returning to Korea was not a probable choice: "My foundation is Los Angeles. This [store] is my whole life except for my wife and kid. As soon as we can, we'll build up what we can."[11] Whatever these Korean Americans chose, the L.A. riots shattered their faith in the American society and the American dream for which they had emigrated from their motherland.

\section{WESTERN AVENUE AND ITS NARRATIVE}

Western Avenue does not treat diverse stories of Korean Americans. But it instead deals with the story of an immigrant family, the Kim's family who came to the United States in the late 1970s. Kim came to Los Angeles in his late thirties with his wife and three children: five-year-old Marian and her two elder brothers, Bobby and Frank.[12] Taking Marian as the center figure of the whole narrative, the film portrays her personal experiences and the story of the other Kim family members through her individual memories; she acts as a narrator who explains their lives after immigration.

Western Avenue ultimately portrays how the American dream of this family develops and then ends in despair, dealing with several concerns, including the American dream of Korean Americans in the first generation, their entrepreneurship, intergenerational gaps, the attitude of Korean Americans toward African Americans, the confrontation between Korean and African Americans, and media descriptions on Korean Americans during the L.A. riots. Utilizing continuity editing and linear narration in dealing with its story, the entire narrative structure of the film is, therefore, based on the continuity of time and space, and it maintains the chain of causality. Following the tradition of transparency, the film is attached to the objective point-of-view at all times, compressing the camera lens, the audience's eye, and the film screen into a single window on the world, as if the spectator is witnessing reality. Location shooting and the realistic organization of the setting bring a more graphic appearance to the film. 
The film breaks its narrative structure into four parts. The first part is a brief introductory sequence recalled by Marian approximately twenty years after immigration. With this sequence, the film portrays the early immigration period of this family when Kim opened his own shop in a black neighborhood after saving a little money through hard work. Like many Korean American merchants' children, Marian grew up in a household where her parents were often absent because of long working hours without days off each week. Since long working hours and no days off are considered peculiar aspects of Korean American-owned small-businesses, this characterization of young Marian becomes natural. She would play around Kim's store after school. At that time, Marian became the only friend of Norman, the son of Kim's African American employee named Louis. She did not have any friends in her new neighborhood, nor did Norman because he had recently moved to this town. This memory of her childhood is also designed to naturalize meetings between her and Norman as adults and is used as a starting point to initiate the development of their relationship from friendship to romantic love. In this sequence, Western Avenue does not conceal a shameful Korean stereotype of African Americans. In the elementary-school scene where other Korean American kids tease Marian because of her friendship with Norman, this stereotype is unveiled; one of these kids says to Marian that "If you touched black people, you would turn into a black girl in a near future." This is an undeniable stereotype that Koreans once held.

The second part of the film consists of five sequences, mostly regarding Marian's personal frustration: she recognizes herself as a minority woman who is treated like an accessory in the white-dominant society. This segment begins with Frank's wedding ceremony sometime in the early 1990s. He, who has a professional career in finance, marries Sally, a secondgeneration Korean American who is working as a CPA. Kim and his wife are now represented as successful middle-class merchants who are living in a suburban residential town, away from the vicinity of his store. The camera pans from left to right to show the overall picture of the appealing, if not splendid, wedding, then cuts back to show Kim and his wife with smiling. Another shot shows grinning Marian. This wedding scene portrays all of the participants as middle-class. Kim and his wife appear so happy that they do not hide their contentment during the ceremony. Kim also enjoys introducing Marian, a junior at Yale University, to other Korean American guests who again offer congratulations on Kim's successful child-rearing. Before Bobby's arrival at the end of the ceremony, Kim seems to be a man who achieved what he wanted through immigration to the United States.

When Bobby, wearing jeans, finally appears to the wedding ceremony, the camera reveals his difference from other people there. He is portrayed as a working-class man, with a rebellious image. He is the colorful character among Kim's three children (and even among all the characters in the film), who outdoes the others in excess, subversive potential, hair style and dress, and suffering. Bobby is the only child who does not satisfy Kim's hope that his children will succeed in getting professional careers in finance, medicine, and the sciences. Unlike Frank and Marian, Bobby did not earn a high-school diploma and is now working as a taxi driver for a Korean American-owned hotel. Thus, Kim seems to regard his younger son as a failure. Bobby is friendly only with Marian among all the family members. When asked which university Bobby is now attending, Kim hesitates to give a specific answer, but Bobby tells what he is doing now without scruple. He is a selfconfident man as much as other middle-class invitees, regardless of whether Kim is ashamed of him or not. Although one guest says to Kim and Bobby that all occupations are equally honorable in the United States, film audiences can catch the cynical implications of this comment. With the differing social status of Kim's three children (or through the distinction between middle-class youths in the wedding ceremony and working-class ones surrounding Bobby in later scenes), the film touches upon class divisions among Korean Americans after their community becomes more stable.

Some days after Frank's wedding, an unexpected familial conflict emerges: Marian informs Kim that she has switched her major from medicine to drama because she wants to become an actress. While Kim and his wife try to persuade Marian to reverse this change, Marian decides that she will do acting. The final shot of this scene represents the chilly atmosphere in their conversation; No light is in the room. The shot fades out after a brief freeze and cuts back to another scene where Frank tries to persuade her not to change her major. Here, the film portrays an intergenerational gap between Marian (a second-generation Korean American) and her parents (first-generation Korean Americans). This gap results from a conflict between these two sides surrounding the Confucian patriarchal perspective, the longstanding cultural ethos of Korea. Western Avenue has already revealed the maintenance of this patriarchal perspective among Korean Americans, particularly, those of the first-generation, in the wedding ceremony. The minister's congratulatory address, mostly delivered through voice-overs, allows the viewer to learn the wife's duties according to Confucianism. It requires women to follow the husband and to respect him as the indisputable head of the family. One guest, who seems to be a successful middleclass Korean American of a similar age to Kim, confirms this perspective again. "If a woman is too much intelligent, she will not be easy to marry." In this scene, we can see Marian's face registering her lassitude at hearing this again. She seems to ignore his assertion, saying that she will do the reverse of what she has been educated to do in the United States after marriage.

While listening to Marian's decision, Kim recommends her to follow his direction in studying medicine again. This is the very patriarchal guidance, regardless of whether his daughter wants or not. In order to maintain his authority, Kim bonds with Frank, his eldest son, and again compelled Marian to follow his guidance. Kim tries to prevent (or at least delay) her from seeking out her own dream, which is unacceptable to him. However, he fails to do so. Faced by Marian's stubborn resistance, Kim instead argues that she will not be his daughter anymore if she continues to do what she wants.[13] For Marian, who learns of the individualism of American culture, however, the traditional patriarchal norm in Korea is considered unacceptable. Therefore, the conflict between them makes a father-and-daughter relationship dangerous: Marian decides to pursue to her dream without parental pressure and leaves from 
L.A. Now she is no longer a proud daughter whom Kim once praised in front of his colleagues. In New Haven, Marian tries to develop her career in acting and completed a film with her boyfriend, Steve. However, Steve abandons Marian after he gets a chance to develop his career in the mainstream industry, saying that he is sick of her non-Oriental attitude.

The third part of the film focuses on Kim's store in crisis, ending in the unexpected deaths of Bobby and Norman during the riots. This part focuses on the period of heightening the black-Korean conflict after "the Soon Ja Du-Latasha Harlins incident" where a fifteen-year-old African American girl was shot to death by a Korean American grocer in an in-store squabble over a shoplifting charge on March 16, 1991. In November 1991, Soon Ja Du was sentenced with a five-year probation, $\$ 500$ fine, 400 hours of community service, and reimbursement of the funeral cost for Harlins.[14] This incident was viewed as the key to the catastrophic collapse of relations between L.A.'s black and Korean communities: "Tensions have been high between South Koreans and black American soldiers since a Korean grocer in Los Angeles shot and killed black teen-ager Latasha Harlins last year for allegedly stealing a bottle of orange juice, according to the Defense Department official. The tension escalated when the grocer, Soon Ja Du, was convicted of voluntary manslaughter in the case but did not receive a prison sentence.”[15]

In the film, African Americans in the street criticized Korean Americans as the killer who shot an innocent girl. Although Kim insists that he does not do harm to anybody, he is now destined to experience this racial conflict in front of his store. Encountered by the shouting of "Koreans! Go home," Kim perceives a crisis that he has never experienced in over twenty years. Furthermore, since "black-owned" becomes an assertion of black power with the emphasis on economic power, Korean American small-businesses in black communities are the most apparent target of this black movement. Some African Americans think of Korean American shopkeepers in black ghettos as "vampires" because these shopkeepers have a tendency to move out of black neighborhoods when they earn enough money to do business with high capital requirements, just as previous ethnic groups such as Jews and Italian Americans did in the 1960s. Kim's store, the representative of Korean American businesses, is now considered the place where Kim exploits black people.

Western Avenue tries to show African Americans' perspectives regarding this conflict, especially that of Norman who becomes a community activist after a three-year imprisonment. The jail is depicted as a "school" that made him recognize the persistence of racial discrimination in the society. In several scenes in which Norman appears, the film emphasizes the racial discrimination that African Americans have felt as an intrinsic injustice of the American system. The black-Korean conflict, therefore, is highlighted through Norman's personal relationships. The conflict first happens between Norman and his father, Louis. When Louis wants to go to his job at Kim's store, Norman asks him not to, as a way to express loyalty to Natasha and other black people. Louis, an employee at Kim's store since it opened, does not accept Norman's inordinate hostility against Korean American stores, although he recognizes African Americans' displeasure at having too many Korean American-owned stores in their communities. A dialogue between them shows their different perspectives in that matter:

Norman: They [Kim and his wife or Korean Americans] are exploiting you. And you stand for them [if you keep working with them].

Louis: Exploitation. Is this a phrase that you learn in jail? I don't know political meanings, but I know I can distinguish who are good folks and bad folks. Kim gives me steady work, and with more patience [than] I deserve sometimes.

The racial conflict is also shown in the relation between Norman and Marian. Norman's hostility against Korean Americans makes him look away from Marian when they accidentally meet at his house or at Kim's store, although they were close as children. From the moment Norman and Marian meet by chance in the theater in a black community, their onceclose relationship starts to recover; they say "hello" for the first time since their youth. In the theater scene where Norman asks Marian if she feels afraid of watching movies in black-filled seats, Marian answers with a smile that she does not, because she once lived and now works here. Through their conversation, the film again displays how African Americans feel about Korean Americans after the "Du-Harlins incident." Norman says that "most Koreans are arrogant and rude. They do not like talking with black people, and smiling with these people. They just look down on people like you're a piece of shit." Although Marian ascribes Norman's criticism to cultural difference, he seldom withdraws his arguments and bluntly replies that he knows that most Korean American shopkeepers are firstgeneration immigrants. But he stresses again that they should follow American etiquette if they want to stay in the United States. Mutual misunderstanding resulting from cultural difference has been one of the most prevalent arguments that Korean Americans have explained why African Americans hate them. Denied by Norman, this argument does not get a persuading power.

From this scene, their relation is developed into a romantic one. Before then, Marian once experienced how she was regarded in a white dominant society. After that experience, Marian seems to pay attention to black people and their arguments: This is divulged through her voice-over in the previous scenes before the first accidental meeting between Marian and Norman at his house. Although they express different values and attitudes toward the black-Korean conflict, Marian and Norman have a shared feeling; they are living as permanent minorities in the country. In the riverside scene after the first kiss in the warehouse of Kim's store, the camera shows the night of the city in glare, then cuts back to their faces in a close-up. Marian and Norman talk about how they were close when they were kids. With the successive frames containing these two persons in middle-ranged shots, the camera portrays the affectionate atmosphere between them. However, they know there is no welcome coming from any race group in the case of interracial love, especially accompanied by the African American. African American-Korean affiliations have a 
tendency to generate both anti-Asian and anti-African American racism. This results in the death of Norman in a later scene.

The development of their romantic relationship is a cinematic contrivance to search for a reconciliatory gesture to cancel out this black-Korean conflict. The film seems to put an emphasis on the point that the black-Korean conflict is based on misunderstandings of each other, and, therefore, that this conflict would resolve through mutual efforts to increase understanding between the two groups. This notion is reemphasized in the relationship between Kim and Louis. They work together for more than ten years and also attain mutual understanding through a common agony created by their intransigent children. For example, their good relation appears in the store scene right before the attack by black rioters: Kim asks Louis to go back to home because the store will be dangerous soon. However, Louis wants to stay and instead asks Kim to leave the store, saying that he will not be hurt if attackers notice him black. They finally tried to protect Kim's store together.

Western Avenue does not conceal the black-Korean conflict. It, furthermore, addresses this conflict by emphasizing black voices. However, when it describes the L.A. riots, the film highlights the Rodney King verdict as the very motivation to the riots. In the scene where Norman and dozens of other African Americans prepare a rally in a black community center the night before the verdict, they already seem to anticipate the "not guilty" delivered by the white-dominant jury. Arguing that causing fear is the only weapon that they have, they decide to make comprehensive protests against racial discrimination. On the day of the Rodney King verdict, angry African Americans fill the streets. The television news delivers the fires in the South Central area and the proclamation of an "emergence measure" by the mayor of Los Angeles.

The riots finally come to Kim's store. A group of angry African Americans attacks the store with fire. While Kim and Louis try, with blank shots, to prevent them from assaulting the store, Marian calls the police in order to get help; she simply listens that the police cannot protect the shop now. The store is left to be defended by private efforts as it is refused by the public protection of the state. Using every blank bullet, Kim and Louis cannot but stay inside and sustain fire attacks until Bobby appears. He comes to the store with another friend even before contacting his father, unlike Frank who is home but does not respond to Marian's call for assistance. Kim and others make barricades to prevent looting and fire attacks. Here, the film clarifies how Korean Americans feel about American broadcasting during the riots. Television introduces the "DuHarlins accident" as a recurrent portrait as it explains why the riots happen and why Korean American businesses are the target of angry African Americans. Marian and Bobby are exasperated at the recurrent showing of Soon Ja Du, arguing that this is the way to turn black anger at Korean Americans. They say that the American media are now making Korean Americans the scapegoat for racial anger.

Waiting for another possible attack, Kim decides to take Marian home and asks Bobby to do so. This decision creates a tragic climax, the unexpected deaths of Bobby and Norman. After Bobby and Marian recognize they cannot get out of the
South Central area occupied by the rioters, they finally confront a group of African Americans while trying to go back to the store: the car is on fire, then Bobby undergoes assault and battery. On the point of being killed, Norman rescues Bobby. He makes Bobby and Marian leave with his own car. While they are going back to Kim's store, two accidents happen. The first is the killing of Norman by a black man who criticizes Norman as the person who only endeavors to protect his girlfriend. The second is the attack on Kim's store by indiscriminate shooting from an unidentified car. Louis is wounded and the store is in flames; it makes Kim too angry. The camera shows a brief moment of silence before another car enters into the screen. Kim suspects it to be the car that attacked him before, although it is Norman's car in which Bobby and Marian are now riding.

The most pathetic part of the film is the scene in which Kim shoots at his children without knowing they are in the car. The camera alternately pictures Kim who is shooting, and Marian and Bobby who are shot. This cross-cutting of shots embodies the most tragic moment for Kim's family after immigrating to the United States. Marian is wounded and falls out of the car. Bobby is dead in the driver's seat with his head drooping down. The sound of the honk is continuously echoed throughout these shots. Recognizing what he did to his son and daughter, Kim wails over his mistake. With the juxtaposition of sound (crying and screaming) and image (flames), the camera cuts back and alternately shows all the characters in despair. While their car is in flames, the screaming Kim clutches Bobby to his chest, groaning Marian lies down in the street, and Louis sighs while leaning against the wall. Though the representation of Kim's despair is quite graphic, it is never fetishized through close-ups, but is kept at a distance.

The last part of this scene shows overall images of this dismal situation through a long shot in high angle, under the search-light of the police helicopter. And it turns into a shot of the store in flames with a full shot: this frame is held, then blurs, and finally overlaps with the tombstones of two youths, Bobby and Norman. The final part of the film is the cemetery scene where Marian is standing in front of Bobby's and Norman's graves. It brings to mind both the frustration of the American dream that Kim's family once held and the futility of interethnic conflicts. Right after this scene, the film ends with a printed epilogue explaining how much damage Korean Americans suffered during the three-day riots, with a series of black and white photographs picturing their post-riot demonstrations against indifferent official assistance.

\section{CONCLUSION: KOREAN AMERICANS AND THEIR AMERICAN DREAMS}

Marian's narration in the beginning sequence provides a clue to how Kim and his wife finally opened their shop: "We arrived at Los Angeles, just with $\$ 800$ in pockets. My parents were working so hard for seventeen hours per day, and they finally opened their own store in three years on Western Avenue [in South Central Los Angeles]." When Kim and his wife immigrated to the United States, they dreamed of becoming rich enough to give their children a better education. For them, 
immigration to the United States was a way to achieve better material lives for themselves and their children. However, their more important hope lay in the mainstream success of their children, who could expect professional or bureaucratic careers through a high-quality education. As Abelmann and Lie note, these dreams are common for Korean Americans in the first generation; they want to achieve social mobility through their children in a new world of opportunity.

For Kim and his wife, the opening of their own store may be a starting point for realizing their dreams. Self-employment is an adaptive response to the lack of educational credentials and linguistic constraints that most first generation Korean Americans confront. Among Korean immigrants, those who earn between $\$ 30,000$ to $\$ 50,000$ a year have a tendency to choose self-employment inside urban ethnic enclaves or innercity ghettos as an alternative route to achieve their American dreams.[16] Kim and his wife cannot afford to embark on an enterprise with high capital requirements, such as a large retail outlet or manufacturing concern. They originally do manual labor to accumulate money and save just enough to open a small convenience store in a poor neighborhood where there is little competition and a high crime rate. They become smallbusiness owners with relatively low start-up capital and limited technological requirements. Kim's family is characterized as an example of Korean entrepreneurship, which was praised as the model minority during the period from the mid-1970s to the end of the 1980s. Before the L.A. riots, the dominant American media insisted that Korean immigrants as self-made entrepreneurs personified the American dream through hard work, frugality, free labor from family members, and a cultural tradition of self-reliance.[17]

Kim's family is also an example of Korean immigrants in the late 1970s. Unlike the 1980s when anti-Americanism became popular in Korea, the 1970s was a decade of escalating positive images of America in the minds of Korean people. The United States was perceived as the colonial liberator and Korean War savior. Unlike the United States, the Korea of the 1970s was an underdeveloped country where authoritarianism was deeply woven into the fabric of everyday life through the controls of the military and police. Therefore, the United States was conceived as a prosperous and freedom-loving country, much different from their mother country. It was a land of opportunity for Koreans until the end of the 1980s when the number of Korean immigrants declined to just one fifth of the peak year of immigration in 1977.[18] The American dream projects a vision of the United States as a place where individual labor and effort determine success and failure. Racism is not a serious consideration. Thus, most Korean immigrants of the 1970s came to the United States without appreciating its long-standing racial problems.

Unaware of the seriousness of racial discrimination in the United States, Kim came to fulfill his dreams in America. However, as Kim understands more about American society, he seems to recognize an unspoken but pervasive American ideology: "whites are the best all the time."[19] In the scene where Kim and Frank try to persuade Marian to continue studying at the medical school instead of transferring to the drama department, Marian argues that she wants to compete as an actor in the mainstream American film industry. Knowing that she has little chance of succeeding in an acting career, Kim says that there are invisible structural limitations on the success of minorities in the United States. Frank explains these invisible restrictions by using the term "glass ceiling." Because the glass ceiling is not apparent until it is reached, it is easy to believe that it does not exist. In a sense, the hopes of minorities seem to be in vain under this invisible restriction.

Western Avenue challenges cherished assumptions about the United States such as that it is a melting pot where diverse ethnic people are able to live without any discrimination. This challenge is explicit in a sequence where Steve breaks faith with her. Together they have completed a film project based on Marian's idea to deal with her life as an immigrant who came as a child to the United States.
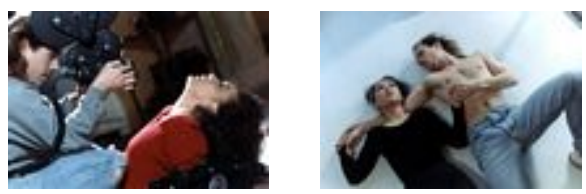

Fig. 2. $<$ Pictures of Marian with Steve $>$

The project finally earns critical acclaim that jump-starts Steve's career in the mainstream film industry. At the same time, Marian is frustrated because she is only recognized as an exotic actor, although she feels that she designed the project.[20] She becomes increasingly frustrated in the party scene after screening the project when the white people recognize her not as an average American like them but as a permanent outsider who is simply speaking English fluently. Marian is now recognizing how she is recognized by the white-dominant perspective, even though she once argued to her father that she was not a Korean but an American. When Steve packs and is about to leave her for another woman (the white woman who shows a passionate interest in him and his film project during the screening session and then in the party), he tells her why he has to leave now, arguing that he is tired of Marian because she does not behave like most Oriental women who are famous for their submissiveness. Now Marian knows what he really wanted from her. Marian is so frustrated that she experiments with drugs before Bobby comes to take her back to Los Angeles. There are no friendly images on white people throughout the film. On the contrary, by celebrating the love between Marian and Norman in later scenes and giving new meaning to the reconciliation between two minority groups, the film provides a romantic fantasy that promotes empowerment through the strategic alliance of frustrated minority groups.

What marks the difference between the narration of this film and the reports of American media is their respective interpretations of the so-called "black-Korean conflict." After scrutinizing reports of mainstream American media about the L.A. riots and the looting of Korean Americans' stores, Abelmann and Lie note that "Nowhere is the distance between ideal and reality greater than in the dominant media framing of the "black-Korean conflict."[21] These media attributed the "black-Korean conflict" as the underlying factor of the violence, implying that Koreans seemed to receive what they deserved. To justify their point, the media stressed tense relations 
between Korean and African Americans, which were exaggerated after the "Soon Ja Du-Latasha Harlins incident" in March 1991. Such images of the attack of Korean Americanowned stores in fires, crying Korean merchants, and angry African-American bystanders flooded the media.

However, Western Avenue depicts the L.A. riots and the looting of Korean American businesses differently in order to challenge this American media portrayal. It acknowledges the tension of the "black-Korean conflict" surrounding shops that Korean Americans manage in black ghettos, but refuses to name this inter-ethnic conflict as the main cause of the riots. The film instead complies with a popular perspective argued by Korean Americans during and after the riots: Korean Americans were set up as the scapegoat of African Americans' anger against deep-rooted racial discriminations in the United States. If Korean Americans caused and deepened racial problems in South Central Los Angeles, why did the riots happen on the day of the first Rodney King verdicts, and, furthermore, why did Korean Americans show much concern over the second verdicts and heave a sigh of relief after hearing "guilty" verdicts for the charged policemen? If there is a serious conflict between these two minority groups, why were there no cases of them killing each other during the riots? The impact of the verdicts in the Rodney King beating case is regarded as the single cause of these urban riots. The "black-Korean conflict" is not at the root of the riots.[22] Therefore, the film criticizes the recurrent television depictions of Soon Ja Du, the Korean shopkeeper who killed a young African American, during the three-day riots as an elaborate tactic to engender interminority conflict.

\section{REFERENCES}

[1] D. Hazen, Inside the L.A. Riots, New York: Institute for Alternative Journalism, 1992, p. 10.

[2] According to the 1990 census in the United States, the total population of Korean Americans was approximately 800,000. Among them, Southern California residents were considered a quarter of that number. However, arguing that many Korean Americans did not register in that census, a Korean-language journal published monthly in the United States estimates that the total number of Korean Americans in 1990 might have been approximately 1.6 million. See Korean JournalNationwide, 1 December 1999, p. 16.

[3] Los Angeles Times, 4 May 1992, A3.

[4] There are two other film works dealing with Los Angeles Riots of 1992 from the Korean-American perspective. These were documentary works: Clash of Colors: LA Riots of 1992 (2012, directed by David Kim) and Pok Dong (2006, directed by Alex Ko). Clash of Colors deals with how the riots affected the Korean American community in Los Angeles, while analyzing the complex social events before, during, and after the six-day catastrophe. Pok Dong examines the haunting impact of the LA riots on an immigrant family and creates a candid look at an immigrant family from Korea and their struggle with life while living the American dream.
[5] I. Yoon, "Self-employment in Business among U.S. Ethnic Groups," Korea Journal of Population and Development Vol. 25, 1996, p. 129.

[6] G. Jeon, The Korean Black Conflicts: A Critical Communication Approach, A Ph.D. dissertation: University of Wisconsin at Madison, 1993.

[7] K. C. Kim, Koreans in the Hood: Conflict with African Americans, Baltimore: The John Hopkins University Press, 1999.

[8] B. G. Wheeler, Black California: The History of AfricanAmerican in the Golden State, New York: Hippocrene Books, 1993, p. 274.

[9] N. Abelmann \& J. Lie, Blue Dreams: Korean Americans and the Los Angeles Riots, Cambridge: Harvard University Press, 1995, p. 184.

[10] I. Yoon, "Who is My Neighbor?: Koreans' Perceptions of Blacks and Latinos As Employees, Employees, Customers, and Neighbors," Development and Society, Vol. 27, No.1, 1998, p. 50.

[11] Los Angeles Times, 4 May 1992, B3.

[12] The film does not provide specific demographic information about the characters, such as their ages or their immigration year. Therefore, I can only presume their ages and immigration year from the film's narrative structure. It is possible to get information on these matters through Marian. When she is attending elementary school, it is at least 3 years after immigration. And she is introduced as a junior of Yale University one or two years ago before the L.A. riots.

[13] A Korean version of patriarchal order has a tendency to define a daughter's resistance against the father as a terrible deviation. See E. Y. Yu, "Women in Traditional and Modern Korea." E. Y. Yu and E. H. Phillips (ed.). Korean Women in Transition: At Home and Abroad, LA: California State University, 1987, pp. 15-28.

[14] Los Angeles Times, 25 November 1991, B4.

[15] Los Angeles Times, 4 May 1992, A6.

[16] G. Jeon, The Korean Black Conflicts: A Critical Communication Approach, A Ph.D. dissertation: University of Wisconsin at Madison, 1993.

[17] N. Abelmann \& J. Lie, Blue Dreams: Korean Americans and the Los Angeles Riots, Cambridge: Harvard University Press, 1995.

[18] Korean immigration to the United States was more than 35,000 annually during the three years between 1985 and 1987. In 1992, however, fewer than 20,000 Koreans immigrated to the United States, the lowest level since 1972 (Los Angeles Times, 15 August 1993, A14). It is impossible to prove the independent effects of the riots on Korean immigration, but there is a possibility that the L.A. riots play a role in the temporary decrease of Korean immigration to the United States.

[19] I employ the phrase of "whites are the best" from Abelmann and Lie's interview with a Korean American. See N. Abelmann \& J. Lie, Blue Dreams: Korean Americans and the Los Angeles Riots, Cambridge: Harvard University Press, 1995, p. 56.

[20] The film shows part of their film project entitled "The Exotic," a footage that is filled with the Oriental image of 
Marian in a Korean-style dance, wearing a Korean traditional robe. In this footage, Marian is characterized as an exotic woman who is naturally alienated from the others. Surrounding her with whites and blacks, it highlights Marian as unique among them. Beneath bluetoned lighting and a dark backdrop, her image is too eroticized. This scene even contains a symbolic sex act between Marian and a white man. The problem is that through this footage the spectator seldom senses Marian's agony at existing between two conflicting cultures. Therefore, the intended meaning of this footage is not easily caught; it is as intricate as the dance movement Marian performs, borrowing it directly from a traditional Korean "Monk's dance." After all, their project fails to introduce her fragile and delicate position in America.

[21] N. Abelmann \& J. Lie, Blue Dreams: Korean Americans and the Los Angeles Riots, Cambridge: Harvard University Press, 1995, p. x.

[22] Yoon emphasized that "contrary to sensational reports in the mass media, most disputes between Korean store owners and their customers are trivial and not violent far from racial bigotry and hate crime." See I. Yoon, "Who is My Neighbor?: Koreans' Perceptions of Blacks and Latinos As Employees, Employees, Customers, and Neighbors," Development and Society, Vol. 27, No.1, 1998, pp. 58-59.

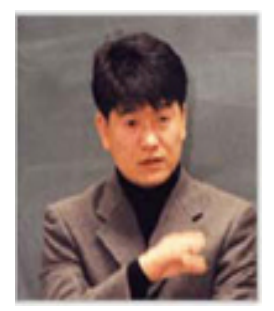

\section{Seung Hyun Park}

$\mathrm{He}$ received Ph.D. in mass commu nication from Indiana University, USA in 2000. Since 2001, he has been with Hallym University. His current research interests deal with the film industry and its performance.

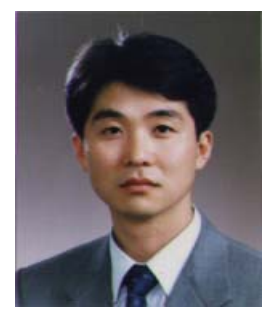

Yeonshik Kim

After working as a television program director for four years, he earned Ph.D. in School of Communication from Yonsei University in 2008. He is now teaching in the Department of Journalism and Mass Communication at Kyungpook University. 